\title{
Behavior of stock prices due to the lock-up period expiration in IPOs and follow-ons
}

\author{
Loveley Talans ${ }^{1}$ \\ (D) https://orcid.org/0000-0001-9541-8060 \\ Email: loveleyt1@al.insper.edu.br
}

\author{
Andrea Maria Accioly Fonseca Minardi ${ }^{1}$ \\ (D) http://orcid.org/0000-0003-3528-910X \\ Email: minardi@insper.edu.br
}

${ }^{1}$ Insper, Departamento de Economia, São Paulo, SP, Brazil

Received on 04.28.2020 - Desk acceptance on 05.08.2020 - $2^{\text {nd }}$ version approved on 09.22.2020 - Ahead of print on 04.02.2021

Editor-in-Chief: Fábio Frezatti

Ad Hoc Associated Editor: Luiz Felipe de Araújo Pontes Girão

\begin{abstract}
The objective of this study was to verify the effects of the lock-up expiration on the behavior of prices and volumes in IPOs and follow-ons in the Brazilian market and to identify factors that may explain the existence and magnitude of abnormal returns. Few studies were found to investigate this phenomenon in Brazil, which were limited to the analysis of IPOs without examining the effect on follow-ons and the construction of abnormal accumulated returns compared to the Ibovespa, instead of benchmarks appropriate to each stock's risk. Lock-up clauses exist to mitigate the problem of information asymmetry in public offers but expose investors to the risk of a price drop after its expiration. Understanding the magnitude of this impact is essential for investors in the stock market. Through this article's analysis, investors will be able to estimate the magnitude of the price variation around the lock-up expiration, what factors explain the returns, and whether there are indications of short selling limitations. The event study method was applied, comparing returns to the Ibovespa and an individual reference portfolio composed of similar companies. Database: 313 offers that occurred on the Brazilian stock market between 2004 and 2019. Evidence of volume increase was found around the expiry of lock-up in IPOs, but the price drop was verified only in companies with private equity funds as shareholders. In follow-ons, in which the asymmetry of information about the issuer is less pronounced, the opposite situation was verified. There are several extensions and lock-up formats worldwide, which provide different impacts on volume and price. This article contributes to the literature when analyzing this event in Brazil and extending the analysis to follow-ons. A possible interpretation for the phenomenon is the restrictions on shortselling in the Brazilian market.
\end{abstract}

Keywords: lock-up, public offers, event study, private equity, market efficiency. 


\section{INTRODUCTION}

With the more significant development and sophistication of Brazil's capital market and the growing demand for greater transparency, clear rules, and equity in the treatment of minority investors, B3 (formerly BM\&FBovespa) announced, in the early 2000s, the creation of Differentiated Levels Corporate Governance Practice. Segments of voluntary adhesion were listed for companies that commit to adopt acceptable corporate governance practices in addition to that required by the legislation in force.

In this context, most new companies intending to issue shares, whether through IPOs or follow-ons, sought to meet the best corporate governance practices to adhere to the differentiated listing segments, expanding access to a greater range of investors and raising the value perception of companies. Thus, it is common to find in the prospectuses of stock offers, the signing of lockup agreements, or agreements in which the controlling shareholders and administrators are obliged, before the institutions offering the offer, not to trade their shares and/or derivatives of these shares during a pre-established period, usually from 90 to 180 days after the event.

Until December 2017, the New Market Regulation, which is the highest standard of corporate governance at B3, provided a progressive and decreasing lock-up. In IPOs, $0 \%$ of the shares held by insiders (controllers, administrators, and other individuals who have access to privileged information and not disclosed to the market) could be traded in the first 180 days after the IPO event. Up to $40 \%$ of insiders' shares could be traded after 180 days, and $100 \%$ could be traded after 360 days. In followons, shares held by insiders could only be traded after 90 days.

With the New Market Regulations effective as of January 2, 2018, the determination to establish a lockup period has become voluntary, negotiated between the underwriter and the issuing company. Notwithstanding the lack of obligation, we did not observe any change in the lock-up clause in the prospectuses of share issues launched after the regulation was changed (3 IPOs and two follow-ons launched in 2018 and 17 follow-ons in 2019). The explanation can be the recurring concern about potential conflicts of interest between controlling shareholders and minority shareholders - institutional investors or individuals who do not have access to the same level of information as insiders of issuing companies, who may have privileged information and use them to obtain advantages, mainly concerning the minority shareholder. It is an asymmetric information problem, a type of market failure that generates an imbalance between the parties (Field \& Hanka, 2001).

Lock-up clauses are found in prospectuses for issuing shares in several countries. In some countries, they are voluntary, defined through negotiation between the underwriter bank and the issuer, such as, for example, the United States and the United Kingdom; in others, they are compulsory, as in Brazil, Malaysia, Germany, France, and Italy. There is no consensus on the ideal duration of the lock-up (Achmadsyah, 2016). In the United Kingdom, the period can vary between 85 and 1,650 days. In the Netherlands, the lock-up must include a minimum period of 365 days. In the United States, the implementation of lock-ups is voluntary, and between 80 and $90 \%$ of IPOs have a 180-day term (Bradley et al., 2014). In the United States, it is also more common to find lock-up clauses with a single maturity. However, there is often a staggered structure in other countries worldwide, with more than one maturity, as in Brazil (Goergen et al., 2006; MohamedArshad et al., 2016).

An increase is expected in the volume of shares offered to the market and, consequently, higher selling pressure on the share price around that date. These increases are expected because the lock-up period's expiration date is disclosed in the offer prospectuses, which are public documents and accessible by any investor. Also, the shares that are subject to the lock-up constitute a large part of the issuing companies' capital and may be traded freely from that date. In the risk factors section of the prospectuses for IPO offers and Brazilian follow-ons, there is mention of the possibility of selling the shares of controllers and insiders, which may create selling pressure on the shares after the lock-up period. While determining the number of shares that (and if) will be sold is not possible, the assets' abnormal negative performance could be arbitrated by investors and, therefore, would tend to be eliminated around the lock-up expiration date. However, the restriction on short selling limits this type of arbitrage (Ofek \& Richardson, 2000). When examining what happens to the stock price around the lock-up expiration, we investigate, indirectly, if there are restrictions on the sale discovered in the Brazilian market, preventing arbitrage before maturity. 
In this context, this article aims to contribute to the international finance literature by analyzing the reaction in the price and volume of shares traded in Brasil, Bolsa, Balcão (B3) around the lock-up period expiration. Although Brazil is a relevant emerging country and has the peculiarity of a staggered lock-up maturity, until the time this article was written, few studies were found none of them published (Castro, 2013; Christensen, 2012; Securato, 2011) - that investigate this phenomenon in the Brazilian market. None of them investigates follow-ons, which are also subject to lock-up clauses but are issues with less information asymmetry than IPOs, since there is a history of quotes and behavior of the broadcaster as a public company.

The existence of private equity investors, often found in pre-IPO companies, would be expected to have a more significant impact on the intensity of the fall in return, as the managers of these funds have a pre-established deadline for divesting and returning capital applied to shareholders, in addition to only receiving eventual performance fees after the return of capital. Although flexible, this term should stimulate a negative relationship between the presence of financial investors and abnormal returns. To examine this hypothesis, this type of investor's possible effect on the abnormal return on shares after the lock-up was also investigated.

The methodology adopted in this work was the event study. The behavior of 157 IPOs and 156 follow-ons carried out in the Brazilian market from 2004 to 2018 was examined, and abnormal patterns and variations in the expected returns for assets were identified after the lock-up period expired. For the calculation of abnormal returns, excess asset returns were compared against two benchmarks: the best-known index in the Brazilian market, the Ibovespa, and a portfolio of shares traded on a risk exchange similar to the issuing company, in terms of book-to-market (BTM) and size, built in a similar way to Ritter (2006).

Analogous to most of the international literature, the results confirmed that in Brazilian IPOs with the shareholding of private equity funds, there was an abnormal negative and significant return (between - $2 \%$ and $-3 \%$ ) around both the first and the second expiration date, although with greater statistical significance and confirmed in all tests only on the first due date. This phenomenon has not been fully arbitrated and may indicate restrictions on short selling in the Brazilian market.

For IPOs of companies not financed by private equity funds, we observed abnormal returns on the lock-up's first maturity date, accompanied by a significant increase in trading volume. A potential explanation is the dominance of family businesses in Brazil, in which the founder or family wants to remain in control, and therefore does not sell shares and perhaps even buy when he/she has the right to trade them. There is evidence that the length of the lock-up period and the corporate structure interfere in the magnitude and the sign of the action's behavior around the clause expiration (Hakim et al., 2012).

However, in follow-ons, there is a drop in price around the lock-up expiration (between $-1.6 \%$ and $-2.9 \%$ ) only for offers from companies not financed by private equity funds, but an abnormal stock trading volume did not accompany this price drop effect. Other variables that had a significant and positive impact on the abnormal return around the lock-up expiration were the equity market value and the allocation to institutional investors; those that had a negative impact were listing on the new market and allocation to retail investors.

\section{THEORETICAL BACKGROUND AND FORMULATION OF HYPOTHESES}

The insertion of the lock-up clause is intended to signal to the market that, during this period, key executives will remain in the company, aligning the interests between the company's shareholders and executives. Insiders will not sell their shares even if there is bad news ahead, so the number of shares offered to the market will be limited, reducing the possibility of imbalances between supply and demand (Field \& Hanka, 2001).

Brav and Gompers (2003) analyzed the role of lock-up in IPOs, proposing three main hypotheses for its existence: (i) signaling the quality of the firm, (ii) commitment instrument to avoid a moral hazard on the part of managers, and (iii) mechanism for underwriters to increase their remuneration. The results support only the hypothesis of commitment: managers of non-profit firms, without support from venture capital funds, with less book-to-market ratio and whose offers were coordinated by lower-quality institutions, tend to have more significant incentives for moral hazard. In this case, establishing more extended lock-up periods represents a sign of management's commitment to offset the high moral hazard. 
Hoque (2011) investigated potential explanations for choosing the type of lock-up contract in IPOs in the United Kingdom, where the extension of the lock-up term has a heterogeneous distribution, ranging from 85 days to 1,650 days. Among his results, he found that the presence of venture capital funds and prestigious underwriters confer a kind of certification on the firm's quality, allowing for more flexible and less restricted lock-up contracts, corroborating the results found by Brav and Gompers (2003).

Field and Hanka (2001) examined 1,948 IPO lockup agreements in the North American capital market, in the period of 10 years, between 1988 and 1997. The analyzed sample had an average lock-up term of 187 days after the IPO. They demonstrated a permanent-growth of $40 \%$ in the average traded volume and a statistically significant abnormal return of $-1.5 \%$ in the three days following the lock-up expiration. They also noted that the magnitude of these effects is approximately three times greater when venture capital funds finance the firm than firms that are not; they found evidence that these shareholders sell their shares more aggressively within a year after the IPO. The authors controlled the regressions by sector, size, listing on the NYSE, cumulative return since the IPO up to 6 days before the lock-up expiration, underwriter's market share, and proportion of shares subject to lock-up, but found no evidence that these variables have a significant impact.

Bradley et al. (2014) examined 2,529 companies that performed IPOs in the United States between 1988 and 1997 and found significant evidence of negative abnormal returns averaging $-0.74 \%$ on the expiry lock-up and $-1.61 \%$ considering five days around the due date. Firms that own venture capital funds ( $45 \%$ of the sample) had, on average, negative returns of $-3 \%$ to $-4 \%$ around the expiration date. Of this group, companies in the technology sector, with the highest returns after the IPO and with dominant underwriters in terms of market share, presented the most significant price declines.

As the expiration date is public information, disclosed in the offer prospectuses, the market should arbitrate the price drop around the expiry of the lock-up, and the negative return should disappear. Ofek and Richardson (2000) argue that this inefficiency cannot be easily exploited, as the shares exhibiting the most significant price declines were not available for rent, making it challenging to open short positions. On the other hand, they could be available at high-interest rates, eliminating potential profits associated with a broad bid-ask spread.

Gibbs and Hao (2018) analyze the daily volume of short selling transactions around the expiry date of the lock-up of 315 IPOs carried out in the United States in the period from 2005 to 2006 . They verify that the level of short selling operations increases in the days before the lock-up expires and decreases after the event, indicating that market agents expect negative abnormal returns to occur. However, consistent with Ofek and Richardson (2000), they could not fully explore this phenomenon.

Evidence of the impact of lock-up expiration differs in terms of magnitude and signal in different countries. Hoque (2011) investigated 831 IPOs on the London Stock Exchange between 1999 and 2006 and found significant abnormal returns after the lock-up expired. Goergen et al. (2006) examined 406 IPOs performed in France and Germany between 1996 and 2000 and found no evidence of abnormal returns. Boreiko and Lombardo (2013) investigated 167 IPOs in the Italian market between 1999 and 2008 and found no evidence of abnormal returns. Mohamed-Arshad et al. (2016) evaluated 292 IPOs between 2003 and 2012 carried out on the Malaysian stock exchange and found a price drop around the lockup expiration. Hakim et al. (2012) investigated the lockup phenomenon in the Middle East and North Africa (MENA). They found that the greater the length of the lock-up period, the greater the price drop, and that this price drop is sharp for family businesses. Gao et al. (2017) investigated a regulatory change in China, which abolished compulsory lock-up, and used a database of institutional investors' offers. They identified that removing the lockup increased institutional investors' offer price and that this effect was more remarkable for issues made by underwriters of lesser reputation and more significant uncertainty. This resulted in a higher launch price and lower underpricing of the stock, i.e., a lower return on the first trading day.

Several studies analyze the first day returns of Brazilian IPOs. Examples, among many others, are Leal (2004), Silva and Famá (2011), and Minardi et al. (2015). Although the underpricing phenomenon is related to the share price's behavior around the lock-up, we found only a few master's theses that investigated the subject in Brazil, and none published at the time of writing this article. Brazilian works results also differ concerning the sign and magnitude of the impact of the lock-up expiration on the share price and how financial investors interfere in this impact. Castro (2013) analyzed 116 IPOs launched between 2004 and 2012 and found evidence that there is a drop in returns around the lock-up maturity and that this effect is smaller for companies invested by private equity funds. Securato (2011) analyzed 77 IPOs from 2000 to 2010 and found significant negative accumulated 
abnormal returns around the lock-up expiry; however, higher for companies that had private equity funds as shareholders. On the other hand, Christensen (2012) obtained opposite results, not finding abnormal returns in 100 IPOs carried out in Brazil between 2004 and 2010. Nevertheless, he detected the existence of abnormal returns in firms that presented high price volatility.
From the literature review, the following hypotheses are made:

$\mathrm{H1}$ : There is an abnormally negative return on public share issues around the lock-up maturity;

$\mathrm{H} 2$ : The magnitude of the abnormal negative return on public equity issues around the lock-up maturity increases for companies invested by private equity funds.

\section{METHODOLOGY AND DATABASE}

\subsection{Event Study}

The event study method was applied in this work, as proposed by Field and Hanka (2001), to examine the impact of the lock-up period expiration on the shares' behavior. Windows from 1 and 5 business days before and from 1, 5, 10, and 22 business days after the event date (lock-up expiration) were analyzed.

The abnormal return of stock $\mathrm{i}$ in $\mathrm{t}(\mathrm{ARi}, \mathrm{t})$ was obtained by Equation 1:

$$
A R_{i, t}=R_{i, t}-R_{\text {portfolio_benchmark }, t}
$$

where $R_{i, t}=\ln \frac{P_{i, t}}{P_{i, t-1}} ; P_{i, t}$ is the closing price of share $\mathrm{i}$ adjusted for earnings and other corporate events on day $t$.

Two benchmark portfolios were used: Ibovespa and a portfolio appropriate to the risk of stock i according to size and book-to-market ratio, as proposed by Ritter (2006).

By comparing the return of an asset to a portfolio of companies comparable in size (market capitalization) and relative value (book-to-market ratio), the abnormal return adjusted to each asset's risk factors is obtained. Thus, the abnormal return is calculated differently from the studies by Field and Hanka (2001) and Ofek and Richardson (2000), which calculate it concerning a market reference index, such as, for example, Ibovespa or S\&P500.

The cumulative abnormal return (CAR) in window $\mathrm{T}$ was estimated by Equation 2 .

$$
C A R_{i, T}=\sum_{t=-j}^{t=k} A R_{i, t}
$$

where $\mathrm{j}=1$ and 5 business days before the event date, and $\mathrm{k}=1,5,10$, and 22 business days after the event date (lock-up expiration).

The average abnormal return of the total sample and the subsamples of IPOs and follow-ons with and without the presence of private equity was calculated, as shown in Equation 3:

$$
\overline{|C A R|}=\frac{\sum_{t=-j}^{t=k} A R_{i, t}}{n}
$$

\subsection{Analysis of the Impact of Private Equity Funds}

In order to analyze whether there is evidence favorable to hypothesis 2, multiple regression by ordinary least squares was performed, according to Equation 4. Robust standard errors were calculated, corrected for heteroskedasticity according to White's method.

$$
C A R_{i}=\beta_{1} * \text { PEBacked }_{i}+\sum_{k=2}^{11}\left(\beta_{k} * \text { control variable }_{i}\right)+\varepsilon_{i}
$$

where PEBacked is a dummy variable equal to 1 if the company had, in its shareholding structure, private equity funds with participation greater than $5 \%$ in its share capital when the offer was made, and 0 otherwise.

Eleven control variables were analyzed, which are detailed below:

- PRIMRIA: percentage of funds raised in the offer and destined for the company. A higher percentage of funds raised for primary purposes may signal to the market that the company will make new investments or optimize its capital structure in preparation for a new investment cycle. Thus, there must be a negative relationship between the percentage allocated to the primary offer and the observed abnormal return, since there is an expectation of growth and value generation in the company with the funds raised and, therefore, less expectation that the shareholders 
will sell their share participation after the lock-up expiration. However, another line of argument could be defended: the larger the primary offer, the lower the secondary offer and, therefore, the less liquidity will be given to shareholders in the offer, which may create selling pressure on shareholders who are held back and subject to lock-up. This control variable was used by Brav and Gompers (2003);

- RET_ACUM_D-5: natural logarithm of the return accumulated by the stock since the IPO or follow-on up to 5 days before the lock-up expiration. Control variable that was used by Field and Hanka (2001);

- UNDERPRICING: difference, in percentage terms, between the closing price of the first trading day and the launch price in the offer. The launch price tends to be lower in the presence of a lock-up, as institutional investors discount the risk of the stock falling at a future date; the higher the expectation of a price drop after the lock-up expires, the greater the underpricing tends to be. A part of underpricing is explained by institutional investors' anticipated drop in price (Gao et al., 2017);

- MKTCAP: natural logarithm of the issuing company's market value, in reais. It intends to investigate whether the size of the issuer influences the behavior of the shares;

- FREE_FLOAT: percentage of the company's total capital circulating in the market after the IPO, with a positive correlation with the shares' liquidity. The higher the percentage of capital in circulation, the less is the effect expected of any selling pressure on prices;

- COORD_LIDER: binary variable assumes the unit value if the lead coordinator of the offer is one of the following underwriters: Itaú BBA, Credit Suisse, or UBS, which had the largest number of leaders in operations since 2004 and together accounted for $56 \%$ of sample offers. The underwriter's quality and experience are expected to influence the profile of investors allocated to the offer and, therefore, the future behavior of the shares. Control variable that was used by Bradley et al. (2014), and Field and Hanka (2001);

- LIST_NM: binary variable indicates whether the company joined the Novo Mercado listing segment on $\mathrm{B} 3$, signaling its high degree of commitment to corporate governance and the transparency of information with the market. The listing at higher levels is expected to reduce the level of information asymmetry between insiders and minority shareholders, reflecting on some influence on the behavior of stock returns after the lock-up period;
- ALOC_VAR: percentage of the total offer allocated to investors in the retail segment, seeking to identify whether the type of buyer influences abnormal returns;

- ALOC_INST: percentage of the total offer allocated to local institutional investors, seeking to identify whether the type of buyer influences abnormal returns;

- ALOC_ESTR: percentage of the total offer allocated to foreign investors, seeking to identify whether the type of buyer influences abnormal returns;

- ANOS: dummy variable, which controls the year the offer was made.

\subsection{Database}

This study sample encompasses all stock issuance events, initial or subsequent, on the Brazilian stock exchange between January 1, 2004, and April 30, 2019. The IPOs of the SBF Group (Centauro) and Neoenergia, carried out in April and June 2019, respectively, were not considered in the sample, as the lock-up agreements remain in effect until the date of this work.

The choice of 2004 as the beginning of the sample is justified by the promulgation of CVM Instruction $n$. 400 , regulating public offers of securities distribution in Brazil, of December 29, 2003, which brought innovations and international practices to the Brazilian market, such as the book building system and the price stabilization mechanism in public offers. The year 2004 is also consistent with other academic works carried out in Brazil and coincides with the highest volume of share issues in the country, making it suitable for the analyses intended with this study.

Offers that occurred through the issuance of Brazilian Depositary Receipts (BDRs), which are subject to specific regulations, and those that were concentrated in the hands of a few investors and, therefore, have low liquidity, were excluded from the sample. The final sample contains 313 offers, of which 157 are IPOs and 156 follow-ons.

The data on the offers (volume, selling shareholders, and the existence of lock-up) were extracted from the preliminary prospectuses, definitive prospectuses, beginning announcements, and closing announcements. In cases where documents related to the offers were not available on the website of the Brazilian Securities and Exchange Commission (CVM) or B3, due to the non-mandatory availability of specific transactions, the companies' Investor Relations websites, banks' websites, bid coordinators, and other secondary sources were consulted. 
The daily closing prices of the shares, the Bovespa index, and the benchmark portfolio, adjusted for earnings and other corporate events, as well as the dates of the offers and traded volumes, were extracted from the Bloomberg database.

Two maturity dates were investigated, 180 and 360 days after IPOs and 90 days after follow-ons, following the guidelines usually adopted by intermediary institutions and $\mathrm{B} 3$ concerning public offerings.

The sample was divided between companies that had private equity or venture capital funds in their shareholding composition before the liquidity event and between initial public offerings and subsequent offers: 84 of the 157 IPOs that occurred since 2004 were supported by private equity funds, which represents more than half of the sample. In turn, only nine follow-ons had private equity, representing less than $10 \%$ of the total of subsequent offers. The presence of private equity investors was verified from the definitive prospectuses of each issue and considered only those shareholders classified as investment funds in participations that held more than 5\% of the issuing company's capital at that time, according to CVM rules in force for disclosing the shareholder base.

\subsection{Building the Appropriate Benchmark Portfolio}

To build an individual reference portfolio for each asset and, therefore, to better estimate the abnormal return, we used the methodology proposed by Ritter (2006), based on the risk factors of Fama and French (1993). Thus, the excess return generated by the lock-up expiration concerning a similar risk portfolio was estimated in terms of book-to-market (BTM) and size.

From a sample of all the shares listed in B3 responsible for at least $90 \%$ of the daily trading sessions, four portfolios weighted by size and BTM were initially built. Companies in the financial segment were excluded from the sample since their high degree of indebtedness, although typical to the sector, is reflected in the BTM index and does not have the same meaning as the high degree of indebtedness of non-financial companies. Also excluded were shares that did not have: (i) daily quotes on at least $90 \%$ of the days in 12 months before the formation of portfolios; or (ii) who performed an IPO or follow-on during the portfolio formation period, considering that there may have been abnormal price volatility after these events. On average. 148 stocks of Brazilian companies made up the sample in the period under analysis.

All returns were calculated daily and continuously using the share price ratio's natural logarithm on day $t$
$\left(P_{i, t}\right)$ divided by the share price on day $\mathrm{t}-1$, adjusted by earnings and other corporate events.

The following procedures were adopted on December 31 of the year $\mathrm{t}-1 \mathrm{o}$ build the benchmark portfolios of each risk class according to the $\mathrm{BTM}$ size and ratio:

- The shares were organized by size and separated into two groups: $\mathrm{S}$ (small - size below the median) and $\mathrm{B}$ (big - size above the median);

- Group S shares were ordered by the BTM index (book value divided by market value, or the ratio between the company's equity value and economic value) and classified into two groups: $\mathrm{SH}$ (BTM above the median) and SL (BTM below the median);

- Group B shares were ordered by the BTM index and classified into two groups: BH (BTM above the median) and BL (BTM below the median);

- Shares of companies in the financial group in year $\mathrm{t}-1$, regardless of size and BTM ratio, were classified in the financial portfolio.

Thus, four portfolios were built based on the size and BTM index. In addition to these four groups, there is an extra group for financial companies, considering this sector's particularities. The IPOs and follow-ons of year $t$ were compared with the appropriate benchmark by size and BTM of each asset, except the companies in the financial sector, compared with the financial portfolio. The five constituted groups serve as controls and will be named, in this study, as the appropriate benchmarks or reference portfolios.

The portfolios were rebalanced on January 1 of year $t$, based on December 31 of year $t 1$.

Table 1 contains the average of the dependent and explanatory variables for the share issues in the sample. Panel A corresponds to IPO emissions, and Panel B corresponds to follow-ons. Private equity funds can be noted to be present in $53.5 \%$ of the sample's IPOs, while these funds supported only $5.7 \%$ of the follow-ons. This may indicate that private equity funds preferentially divest from all of their holdings after the IPO lock-up period expires, without issuing a new subsequent offer for sale in the secondary market.

More than $80 \%$ of the IPOs were noted to be listed in the Novo Mercado segment of B3, the highest corporate governance level on the stock exchange, an index significantly higher than the $66 \%$ observed in followons. The performance of IPOs between the launch up to 5 days before the lock-up expiration is negative by $-1.4 \%$ in the presence of private equity, which is not repeated in 
the absence of financial shareholders follow-ons, whose accumulated returns positive and higher than $5.0 \%$. This could mean a market arbitrage anticipating the fall after the expiry of the lock-up and sale period of the shares of the private equity funds.

Also, IPOs with a private equity presence have a lower percentage of primary offerings, higher quality underwriters, and a higher percentage of allocation to foreign investors. In follow-ons, in turn, there is a lower percentage of primary offer and less allocation to retail in issues supported by private equity funds. The observed results can be explained, at least partially, because the outflow of private equity raises the percentage of the secondary offer and the governance "seal" brought by the private equity fund contributes to increasing the attractiveness of the issue to foreign investors.

\section{Table 1}

Average of dependent and explanatory variables, segmented into a total sample, a subsample of issuers with private equity, and a subsample of issuers without private equity

\begin{tabular}{|c|c|c|c|c|}
\hline \multicolumn{5}{|c|}{ Panel A: IPOs } \\
\hline Variable & Total & With PE & Without PE & Diff \\
\hline PEBACKED & 0.535 & 1.000 & 0.000 & 1.000 \\
\hline PRIMRIA & 0.657 & 0.585 & 0.740 & $-0.154^{* * *}$ \\
\hline RET ACUM D5 & 0.021 & -0.014 & 0.060 & $-0.074^{*}$ \\
\hline UNDERPRICING & 0.047 & 0.054 & 0.040 & 0.014 \\
\hline MKTCAP & 7.664 & 7.566 & 7.776 & -0.209 \\
\hline FREE FLOAT & 0.364 & 0.380 & 0.345 & $0.034^{*}$ \\
\hline COORD LIDER & 0.592 & 0.714 & 0.452 & $0.262^{* * *}$ \\
\hline LIST NM & 0.809 & 0.786 & 0.836 & -0.049 \\
\hline ALOC VAR & 0.083 & 0.080 & 0.087 & -0.007 \\
\hline ALOC INST & 0.201 & 0.194 & 0.209 & -0.015 \\
\hline ALOC ESTR & 0.644 & 0.677 & 0.605 & $0.072^{* * *}$ \\
\hline OBS & 157 & 84 & 73 & 11 \\
\hline \multicolumn{5}{|c|}{ Panel B: Follow-ons } \\
\hline Variable & Total & With PE & Without PE & Diff \\
\hline PEBACKED & 0.057 & 1.000 & 0.000 & 1.000 \\
\hline PRIMRIA & 0.591 & 0.222 & 0.613 & $-0.391^{* * *}$ \\
\hline RET ACUM D5 & 0.050 & 0.051 & 0.050 & 0.001 \\
\hline UNDERPRICING & 0.052 & 0.034 & 0.053 & -0.019 \\
\hline MKTCAP & 8.674 & 8.918 & 8.658 & 0.259 \\
\hline COORD LIDER & 0.526 & 0.556 & 0.524 & 0.031 \\
\hline LIST NM & 0.660 & 0.778 & 0.653 & 0.124 \\
\hline ALOC VAR & 0.063 & 0.028 & 0.065 & $-0.037^{* *}$ \\
\hline ALOC INST & 0.266 & 0.210 & 0.270 & -0.060 \\
\hline ALOC ESTR & 0.536 & 0.612 & 0.531 & 0.080 \\
\hline OBS & 156 & 9 & 147 & -138 \\
\hline
\end{tabular}

Note: The sample consists of initial public offerings and subsequent offers launched in the Brazilian market between 2004 and 2019. PEBACKED corresponds to the dummy variable that assumes value 1 if the company had a private equity fund as a shareholder before the launch of the offer, PRIMRIA to the percentage of the primary offer, RET ACUM D5 to the cumulative abnormal return of the launch of the offer up to 5 days before the lock-up expiration, UNDERPRICING to the abnormal return on the first trading day after the launch, MKTCAP to the market value of the issuing company's equity, free float to the percentage of shares traded on the stock exchange, COORD LIDER if the leading underwriter is Itaú BBA, Credit Suisse, or UBS, LIST NM to a dummy that assumes value 1 if the company is listed on Novo Mercado, ALOC VAR, ALOC INST, and ALOC ESTR to the percentage of the offer allocated to retail, institutional, and foreign investors respectively.

*,**, and ${ }^{* * *}$ represent statistically significant at $10 \%, 5 \%$, and $1 \%$, respectively.

Source: Prepared by the authors. 


\section{RESULTS}

Table 2 presents the average values of the cumulative abnormal return (CAR) in the total sample of IPOs, and in the subsamples of IPOs with private equity and without private equity, in maturities of 180 days and 360 days. Panel A corresponds to the CAR built from the Ibovespa benchmark, and Panel B built from the benchmark adjusted to the risk of each issue in terms of size and BTM, according to the methodology proposed by Ritter (2006).

Table 2

Averages of IPO CARs around the two lock-up expiration dates (180 and 360 days)

\begin{tabular}{|c|c|c|c|c|c|c|}
\hline \multicolumn{7}{|c|}{ PANEL A: CAR estimated by the difference between the issue return on day $t$ and the Ibovespa return on day $t$} \\
\hline \multirow{2}{*}{$\begin{array}{l}\text { CAR } \\
\text { (du) }\end{array}$} & \multicolumn{3}{|c|}{ IPO - 180 days } & \multicolumn{3}{|c|}{ IPO - 360 days } \\
\hline & Total & With PE & Without PE & Total & With PE & Without PE \\
\hline-1 to +1 & $\begin{array}{l}0.14 \% \\
(0.42)\end{array}$ & $\begin{array}{l}0.06 \% \\
(0.13)\end{array}$ & $\begin{array}{l}0.23 \% \\
(0.50)\end{array}$ & $\begin{array}{c}-0.10 \% \\
(-0.29)\end{array}$ & $\begin{array}{c}-0.16 \% \\
(-0.34)\end{array}$ & $\begin{array}{c}-0.04 \% \\
(-0.07)\end{array}$ \\
\hline-5 to +5 & $\begin{array}{c}-0.48 \% \\
(-0.73) \\
\end{array}$ & $\begin{array}{c}-0.83 \% \\
(-0.84) \\
\end{array}$ & $\begin{array}{l}-0.08 \% \\
(-0.09) \\
\end{array}$ & $\begin{array}{c}-0.65 \% \\
(-0.79)\end{array}$ & $\begin{array}{c}-1.15 \% \\
(-0.97)\end{array}$ & $\begin{array}{c}-0.08 \% \\
(-0.07)\end{array}$ \\
\hline 0 to +1 & $\begin{array}{l}0.06 \% \\
(0.24)\end{array}$ & $\begin{array}{l}0.16 \% \\
(0.42)\end{array}$ & $\begin{array}{c}-0.05 \% \\
(-0.12)\end{array}$ & $\begin{array}{c}-0.04 \% \\
(-0.17) \\
\end{array}$ & $\begin{array}{c}-0.03 \% \\
(-0.08)\end{array}$ & $\begin{array}{c}-0.06 \% \\
(-0.18)\end{array}$ \\
\hline 0 to +5 & $\begin{array}{c}-0.12 \% \\
(-0.22) \\
\end{array}$ & $\begin{array}{c}-0.88 \% \\
(-1.12) \\
\end{array}$ & $\begin{array}{c}0.73 \% \\
(0.98) \\
\end{array}$ & $\begin{array}{c}-0.67 \% \\
(-1.03) \\
\end{array}$ & $\begin{array}{c}-0.97 \% \\
(-1.11) \\
\end{array}$ & $\begin{array}{c}-0.32 \% \\
(-0.33) \\
\end{array}$ \\
\hline 0 to +10 & $\begin{array}{c}-0.04 \% \\
(-0.06)\end{array}$ & $\begin{array}{c}-1.80 \% * * \\
(-1.74)\end{array}$ & $\begin{array}{c}2.01 \% * * \\
(2.21)\end{array}$ & $\begin{array}{c}-0.20 \% \\
(-0.26)\end{array}$ & $\begin{array}{c}-0.02 \% \\
(-0.01)\end{array}$ & $\begin{array}{c}-0.41 \% \\
(-0.43)\end{array}$ \\
\hline 0 to +22 & $\begin{array}{c}0.42 \% \\
(0.40)\end{array}$ & $\begin{array}{c}-2.12 \%^{*} \\
(-1.44)\end{array}$ & $\begin{array}{c}3.45 \% \text { *** } \\
(2.47)\end{array}$ & $\begin{array}{c}-2.11 \% * * \\
(-1.85)\end{array}$ & $\begin{array}{c}-3.03 \% * * \\
(-1.95)\end{array}$ & $\begin{array}{c}-1.05 \% \\
(-0.62)\end{array}$ \\
\hline \multicolumn{7}{|c|}{$\begin{array}{l}\text { PANEL B: CAR estimated by the difference between the issue return on day } t \text { and the } \\
\text { benchmark return appropriate to the issue risk concerning size and BTM on day } t\end{array}$} \\
\hline \multirow{2}{*}{$\begin{array}{l}\text { CAR } \\
\text { (du) }\end{array}$} & \multicolumn{3}{|c|}{ IPO - 180 days } & \multicolumn{3}{|c|}{ IPO - 360 days } \\
\hline & Total & With PE & Without PE & Total & With PE & Without PE \\
\hline-1 to +1 & $\begin{array}{c}0.47 \% \\
(1.53)\end{array}$ & $\begin{array}{l}0.38 \% \\
(0.88)\end{array}$ & $\begin{array}{c}0.59 \% * \\
(1.30)\end{array}$ & $\begin{array}{l}-0.07 \% \\
(-0.22)\end{array}$ & $\begin{array}{l}-0.12 \% \\
(-0.27)\end{array}$ & $\begin{array}{l}-0.03 \% \\
(-0.04)\end{array}$ \\
\hline-5 to +5 & $\begin{array}{c}0.21 \% \\
(0.33) \\
\end{array}$ & $\begin{array}{c}-0.06 \% \\
(-0.06) \\
\end{array}$ & $\begin{array}{c}0.52 \% \\
(0.64) \\
\end{array}$ & $\begin{array}{l}-0.15 \% \\
(-0.22) \\
\end{array}$ & $\begin{array}{l}-0.51 \% \\
(-0.538) \\
\end{array}$ & $\begin{array}{l}0.25 \% \\
(0.28) \\
\end{array}$ \\
\hline 0 to +1 & $\begin{array}{l}0.26 \% \\
(1.04)\end{array}$ & $\begin{array}{c}0.27 \% \\
(0.78)\end{array}$ & $\begin{array}{l}0.25 \% \\
(0.67)\end{array}$ & $\begin{array}{c}0.07 \% \\
(0.32)\end{array}$ & $\begin{array}{r}0.12 \% \\
(0.40)\end{array}$ & $\begin{array}{c}0.01 \% \\
(0.02)\end{array}$ \\
\hline 0 to +5 & $\begin{array}{c}0.19 \% \\
(0.38)\end{array}$ & $\begin{array}{c}-0.58 \% \\
(-0.79)\end{array}$ & $\begin{array}{c}1.05 \% * \\
(1.57)\end{array}$ & $\begin{array}{c}-0.23 \% \\
(-0.41)\end{array}$ & $\begin{array}{c}-0.52 \% \\
(-0.66) \\
\end{array}$ & $\begin{array}{l}0.11 \% \\
(0.14) \\
\end{array}$ \\
\hline 0 to +10 & $\begin{array}{l}0.46 \% \\
(0.70)\end{array}$ & $\begin{array}{c}-1.09 \% \\
(-1.20)\end{array}$ & $\begin{array}{c}2.25 \% \text { *** } \\
(2.62)\end{array}$ & $\begin{array}{l}0.29 \% \\
(0.40)\end{array}$ & $\begin{array}{l}0.22 \% \\
(0.18)\end{array}$ & $\begin{array}{l}0.38 \% \\
(0.43)\end{array}$ \\
\hline 0 to +22 & $\begin{array}{c}1.44 \% * \\
(1.49)\end{array}$ & $\begin{array}{c}-0.62 \% \\
(-0.44)\end{array}$ & $\begin{array}{c}3.87 \% * * * \\
(3.05)\end{array}$ & $\begin{array}{c}-1.02 \% \\
(-0.93)\end{array}$ & $\begin{array}{c}-2.52 \% * * \\
(-1.68)\end{array}$ & $\begin{array}{l}0.71 \% \\
(0.45)\end{array}$ \\
\hline
\end{tabular}

Note: The value of $t$-statistics is shown in parentheses.

*,**, and ${ }^{* * *}$ represent statistically significant at $10 \%, 5 \%$, and $1 \%$, respectively.

Source: Prepared by the authors.

In Panel $\mathrm{A}$, when considering the total sample, no negative abnormal returns are observed around the first lock-up due date; however, after 22 days of the second maturity, there is a significant accumulated drop in return, equal to $-2.11 \%$. This result is in line with hypothesis 1 and consistent with evidence found in the United States, MENA, Malaysia, and the United Kingdom. However, when analyzing Panel B, this evidence is not supported. In other words, when adopting a more robust methodology for calculating the CAR, there is no confirmation that the lock-up expiration on average results in negative returns for Brazilian stocks. As several of the aforementioned international studies used country stock indexes as a benchmark, without adjusting to the issuers' risk, in some cases, the negative effect of the return to the total stock market may not be significant on average. 
When analyzing the private equity sample, the lockup's negative effect is found to be entirely directed by companies that have financial shareholders, incentives, and pressure to sell their shareholding position as soon as they are free of the restriction. In Panel A, ten days after the first lock-up stage expiration (180 days), a negative cumulative abnormal return is observed, which also appears 22 days after the second lock-up stage expiration (360 days). This drop is of the order of $-2 \%$ to $-3 \%$ for companies financed by private equity funds. In Panel B, there is a negative and significant effect 22 days after the second lock-up stage expiration (360 days), of the order of $-2.5 \%$. Therefore, hypothesis 2 is confirmed, i.e., the fall in the share price is higher for companies financed by private equity funds, and the evidence for the Brazilian stock market is in line with most of the international literature.

This result is also in line with Ofek and Richardson (2000), indicating that the lock-up phenomenon in companies with financial shareholders is not fully explored by arbitrators, possibly due to restrictions on short selling existing in the Brazilian market. The existence of a greater sales movement in offers with private equity may indicate the exit of the fund from the first maturity or investors selling shares for a possible exit of the private equity funds from the management of the companies.

In Panel A, the IPOs of companies not invested by private equity funds presented abnormally positive returns in the first window, after ten days of expiration (2.01\%); however, they presented a non-significant fall in the returns in the second window. Panel B confirms the significant price increase in initial private equity offers 22 days after the lock-up expiration. Therefore, the Brazilian result differs from that found in the United States, in which both the sample with and without private equity present negative abnormal returns around the lock-up expiration. A potential explanation, which deserves to be investigated in new studies, is that the Brazilian stock market is dominated by family companies, who wish to maintain control and, therefore, have no incentive or interest in selling their shares after the restriction window. Hakim et al. (2012) found evidence, for MENA, that the reaction to the lock-up is influenced by the duration of the window and the fact that the company is or is not familiar.

Table 3 shows the volume variations that occurred after the lock-up expired at different time intervals for IPOs. In the presence of private equity, the volume traded in the period of 2 days after the expiration of the first lock-up reached a level $25 \%$ higher than the volume traded on the expiration day. After one month of the event, although the volume traded continues to be $12 \%$ higher than the initial day, it no longer has statistical significance, following the insignificant fall in return observed in Table 2. By presenting relevant and significant growth of $32 \%$ in the second window, the volume traded is in line with the increase in sales and the drop in prices observed in IPOs with private equity. While in the presence of private equity, the average growth in volume traded was lower than the sample without private equity, there was no statistical significance when comparing the averages.

Table 3

Average variation in volumes traded after the expiry of IPO lock-up dates

\begin{tabular}{ccccccc}
\hline \multirow{2}{*}{$\Delta$ Volume (\%) } & \multicolumn{3}{c}{ IPO - 180 days } & \multicolumn{3}{c}{ IPO - 360 days } \\
\cline { 2 - 7 } & Total & With PE & Without PE & Total & With PE & Without PE \\
\hline \multirow{2}{*}{0 to +2} & $24.47 \% * *$ & $25.70 \% * *$ & $23.03 \%$ & $5.92 \%$ & $-2.14 \%$ & $15.33 \%$ \\
& $(1.97)$ & $(1.86)$ & $(1.06)$ & $(0.55)$ & $(-0.16)$ & $(0.88)$ \\
\hline \multirow{2}{*}{0 to +22} & $12.86 \%$ & $12.11 \%$ & $13.75 \%$ & $43.92 \% * * *$ & $32.75 \% * * *$ & $56.77 \% * * *$ \\
& $(1.04)$ & $(0.76)$ & $(0.71)$ & $(3.54)$ & $(2.49)$ & $(2.57)$ \\
\hline
\end{tabular}

Note: The value of $t$-statistics is shown in parentheses.

${ }^{*}, * *$, and ${ }^{* * *}$ represent statistically significant at $10 \%, 5 \%$, and $1 \%$, respectively.

Source: Prepared by the authors.

As the secondary issues have less information asymmetry, since there is already a history of the behavior of the shares before the launch, and there is also only one lock-up expiration date, we redid the studies made on IPOs, to analyze how the expiration lock-up system interferes with the behavior of subsequent offer actions.
Panel A of Table 4 Panel A of Table 4 presents the average CAR values, built concerning Ibovespa, in the total sample of follow-ons, follow-ons with private equity, and followons without private equity, around the lock-up period expiration, 90 days. Panel B contains the results of the CAR built with the risk-adjusted benchmark. 
Table 4

Averages of follow-on CARs around the two lock-up expiration dates (180 and 360 days)

\begin{tabular}{|c|c|c|c|}
\hline \multicolumn{4}{|c|}{ PANEL A: CAR estimated by the difference between the issue return on day $t$ and the Ibovespa return on day $t$} \\
\hline \multirow{2}{*}{$\begin{array}{l}\text { CAR } \\
\text { (du) }\end{array}$} & \multicolumn{3}{|c|}{ Follow-on - 90 days } \\
\hline & Total & With PE & Without PE \\
\hline-1 to +1 & $\begin{array}{c}-0.22 \% \\
(-0.91) \\
\end{array}$ & $\begin{array}{c}-0.92 \% \\
(-0.94) \\
\end{array}$ & $\begin{array}{c}-0.18 \% \\
(-0.71) \\
\end{array}$ \\
\hline-5 to +5 & $\begin{array}{c}-0.23 \% \\
(-0.45) \\
\end{array}$ & $\begin{array}{c}1.98 \% * \\
(1.41) \\
\end{array}$ & $\begin{array}{c}-0.36 \% \\
(-0.66) \\
\end{array}$ \\
\hline 0 to +1 & $\begin{array}{c}-0.23 \% * \\
(-1.29) \\
\end{array}$ & $\begin{array}{c}-1.20 \% * * \\
(-2.00) \\
\end{array}$ & $\begin{array}{c}-0.17 \% \\
(-0.94) \\
\end{array}$ \\
\hline 0 to +5 & $\begin{array}{c}-0.22 \% \\
(-0.56) \\
\end{array}$ & $\begin{array}{l}0.73 \% \\
(0.37) \\
\end{array}$ & $\begin{array}{c}-0.27 \% \\
(-0.69) \\
\end{array}$ \\
\hline 0 to +10 & $\begin{array}{c}-1.08 \% * * \\
(-1.83)\end{array}$ & $\begin{array}{l}1.56 \% \\
(0.89)\end{array}$ & $\begin{array}{c}-1.24 \% * * \\
(-2.01)\end{array}$ \\
\hline 0 to +22 & $\begin{array}{c}-2.61 \% * * * \\
(-3.54)\end{array}$ & $\begin{array}{r}2.00 \% \\
(0.55) \\
\end{array}$ & $\begin{array}{c}-2.85 \% * * * \\
(-3.80)\end{array}$ \\
\hline \multicolumn{4}{|c|}{$\begin{array}{l}\text { PANEL B: CAR estimated by the difference between the issue return on day } t \text { and the } \\
\text { benchmark return appropriate to the issue risk concerning size and BTM on day } t\end{array}$} \\
\hline \multirow{2}{*}{$\begin{array}{l}\text { CAR } \\
\text { (du) }\end{array}$} & \multicolumn{3}{|c|}{ Follow-on - 90 days } \\
\hline & Total & With PE & Without PE \\
\hline-1 to +1 & $\begin{array}{l}-0.21 \% \\
(-0.86)\end{array}$ & $\begin{array}{l}-0.13 \% \\
(-0.12)\end{array}$ & $\begin{array}{l}-0.21 \% \\
(-0.85)\end{array}$ \\
\hline-5 to +5 & $\begin{array}{c}-0.40 \% \\
(-0.82) \\
\end{array}$ & $\begin{array}{l}1.75 \% \\
(1.24) \\
\end{array}$ & $\begin{array}{c}-0.52 \% \\
(-1.03) \\
\end{array}$ \\
\hline 0 to +1 & $\begin{array}{c}-0.13 \% \\
(-0.73) \\
\end{array}$ & $\begin{array}{c}-0.63 \% \\
(-0.90)\end{array}$ & $\begin{array}{c}-0.10 \% \\
(-0.54)\end{array}$ \\
\hline 0 to +5 & $\begin{array}{c}-0.18 \% \\
(-0.51)\end{array}$ & $\begin{array}{r}0.48 \% \\
(0.30)\end{array}$ & $\begin{array}{c}-0.22 \% \\
(-0.60)\end{array}$ \\
\hline 0 to +10 & $\begin{array}{c}-0.89 \% * \\
(-1.62)\end{array}$ & $\begin{array}{c}0.89 \% \\
(0.53)\end{array}$ & $\begin{array}{c}-0.99 \% * * \\
(-1.74)\end{array}$ \\
\hline 0 to +22 & $\begin{array}{c}-1.41 \% * * \\
(-1.98)\end{array}$ & $\begin{array}{r}2.74 \% \\
(0.74)\end{array}$ & $\begin{array}{c}-1.63 \% * * \\
(-2.24)\end{array}$ \\
\hline
\end{tabular}

Note: The value of $t$-statistics is shown in parentheses.

*,**, and *** represent statistically significant at 10\%, 5\%, and 1\%, respectively.

Source: Prepared by the authors.

The results confirm the existence of negative cumulative abnormal returns for the total sample of follow-ons after the lock-up expiration $(-1.41 \%$ to $-2.61 \%)$, as predicted by hypothesis 1 , and this occurs both with the CAR built with Ibovespa (Panel A) and with the CAR built with the emission risk-adjusted index (Panel B). It is interesting to note that this negative effect is driven by issues of companies not financed by private equity funds. After 22 days after the expiration of the follow-ons lock-up of companies financed by private equity, the cumulative returns are positive, indicating less selling pressure by this type of investor after the lock-up expiration in follow-ons.

Table 5 shows the volume variations that occurred after the lock-up expired in subsequent offers at different time intervals. The results demonstrate no significant volume variations in any of the analyzed intervals in the total sample, and this result is maintained in the subsamples with and without private equity.
Table 5

Average variation in volumes traded after the date of lock-up expiration in follow-ons

\begin{tabular}{cccc}
\hline \multirow{2}{*}{$\Delta$ Volume (\%) } & \multicolumn{3}{c}{ Follow-on - 90 days } \\
\cline { 2 - 4 } & Total & With PE & Without PE \\
\hline \multirow{2}{*}{0 to +2} & $0.40 \%$ & $-12.51 \%$ & $-1.14 \%$ \\
& $(0.04)$ & $(-0.43)$ & $(0.13)$ \\
\hline \multirow{2}{*}{0 to +22} & $-0.51 \%$ & $-18.19 \%$ & $0.40 \%$ \\
& $(-0.05)$ & $(-1.24)$ & $(0.04)$ \\
\hline
\end{tabular}

Note: The value of t-statistics is shown in parentheses.

*,**, and *** represent statistically significant at 10\%, 5\%, and $1 \%$, respectively.

Source: Prepared by the authors.

Table 6 contains the results obtained in the regression of Equation 4 for IPOs and follow-ons with the CARs calculated with Ibovespa and similar risk, size, and BTM benchmarks. The regressions confirm the results of the study of events: in IPOs, the presence of private equity 
negatively and significantly impacts the CAR on the first expiration date, but insignificantly on the second maturity (360 days), and this result is observed both with Ibovespabased CAR and the one that uses the risk-adjusted portfolio of the issue as a benchmark. When controlled by all other variables, the presence of private equity funds in the issuer's shareholding structure decreases the return by around $5 \%$ to $6 \%$ around the first lock-up stage's maturity. In followons, private equity funds' presence does not change the price drop significantly after the lock-up expiration.

Table 6

Regression results in Equation 4 with robust standard errors

\begin{tabular}{|c|c|c|c|c|c|c|}
\hline \multirow[b]{2}{*}{$\begin{array}{l}\text { Reference } \\
\text { portfolio }\end{array}$} & \multicolumn{4}{|c|}{ IPO } & \multicolumn{2}{|c|}{ FOLLOW-ON } \\
\hline & Ibovespa & Risk-adjusted & Ibovespa & Risk-adjusted & Ibovespa & Risk-adjusted \\
\hline LOCK-UP (DAYS) & 180 & 180 & 360 & 360 & 90 & 90 \\
\hline \multirow{2}{*}{ PEBACKED } & $-0.0623 * * *$ & $-0.0509^{* *}$ & 0.0095 & -0.0019 & 0.0636 & 0.0608 \\
\hline & $(-2.98)$ & $(-2.54)$ & $(0.35)$ & $(-0.08)$ & $(1.54)$ & $(1.46)$ \\
\hline \multirow{2}{*}{ PRIMRIA } & -0.0467 & -0.0226 & 0.0006 & 0.0037 & 0.0268 & 0.0167 \\
\hline & $(-1.41)$ & $(-0.68)$ & $(0.02)$ & $(0.09)$ & $(1.65)$ & $(1.10)$ \\
\hline \multirow{2}{*}{ RET_ACUM_D5 } & -0.0187 & -0.0372 & 0.0340 & 0.0303 & 0.0768 & 0.0231 \\
\hline & $(-0.46)$ & $(-0.99)$ & (1.13) & (1.09) & $(1.00)$ & $(0.29)$ \\
\hline \multirow{2}{*}{ UNDERPRICING } & 0.0580 & 0.0485 & 0.0589 & 0.0125 & 0.153 & 0.101 \\
\hline & $(0.55)$ & $(0.50)$ & $(0.43)$ & $(0.10)$ & (1.38) & $(1.01)$ \\
\hline \multirow{2}{*}{ MKTCAP } & 0.0007 & 0.0001 & $0.0204^{* *}$ & 0.0127 & -0.0044 & -0.0051 \\
\hline & $(0.08)$ & $(0.02)$ & $(2.00)$ & $(1.36)$ & $(-0.64)$ & $(-0.82)$ \\
\hline \multirow{2}{*}{ FREE_FLOAT } & 0.0353 & -0.0033 & -0.0154 & -0.0196 & & \\
\hline & $(0.57)$ & $(-0.06)$ & $(-0.15)$ & $(-0.19)$ & & \\
\hline \multirow{2}{*}{ COORD_LIDER } & -0.0025 & 0.0105 & -0.0122 & -0.0096 & 0.0129 & 0.0099 \\
\hline & $(-0.12)$ & $(0.53)$ & $(-0.50)$ & $(-0.43)$ & $(0.87)$ & $(0.70)$ \\
\hline \multirow{2}{*}{ LIST_NM } & 0.0317 & 0.0401 & 0.0291 & 0.0204 & $-0.0484^{* *}$ & $-0.0515^{* * *}$ \\
\hline & $(1.16)$ & $(1.55)$ & $(0.91)$ & $(0.60)$ & $(-2.53)$ & $(-2.84)$ \\
\hline \multirow{2}{*}{ ALOC_VAR } & $-0.848^{* *}$ & $-0.721^{* *}$ & 0.660 & 0.669 & -0.0426 & 0.0099 \\
\hline & $(-2.39)$ & $(-2.17)$ & $(1.25)$ & (1.38) & $(-0.34)$ & $(0.09)$ \\
\hline \multirow{2}{*}{ ALOC_INST } & -0.118 & -0.0948 & -0.0744 & -0.0319 & $0.0887^{*}$ & 0.0605 \\
\hline & $(-0.95)$ & $(-0.78)$ & $(-0.51)$ & $(-0.23)$ & $(1.74)$ & $(1.31)$ \\
\hline \multirow{2}{*}{ ALOC_ESTR } & -0.0213 & -0.0387 & -0.107 & -0.102 & 0.0130 & -0.0032 \\
\hline & $(-0.26)$ & $(-0.48)$ & $(-0.97)$ & $(-0.95)$ & $(0.34)$ & $(-0.09)$ \\
\hline \multirow{2}{*}{ _cons } & 0.130 & 0.118 & -0.165 & -0.0942 & -0.0165 & 0.0311 \\
\hline & $(1.11)$ & $(1.06)$ & $(-1.07)$ & $(-0.61)$ & $(-0.22)$ & $(0.48)$ \\
\hline $\mathbf{N}$ & 143 & 142 & 136 & 135 & 127 & 127 \\
\hline $\mathbf{R}^{2}$ & 0.1272 & 0.1031 & 0.1092 & 0.1125 & 0.1357 & 0.1032 \\
\hline
\end{tabular}

Note: The sample consists of initial public offerings and subsequent offers launched in the Brazilian market between 2004 and 2019. PEBACKED corresponds to the dummy variable that assumes value 1 if the company had a private equity fund as a shareholder, PRIMRIA to the percentage of the primary offer, RET ACUM D5 to the cumulative abnormal return of the launch of the offer up to 5 days before the lock-up expiration, UNDERPRICING to the abnormal return on the first trading day after the launch, MKTCAP to the market value of the issuing company's equity, free float to the percentage of shares traded on the stock exchange, COORD LIDER if the leading underwriter is Itaú BBA, Credit Suisse, or UBS, LIST NM to a dummy that assumes value 1 if the company is listed on Novo Mercado, ALOC VAR, ALOC INST, and ALOC ESTR to the percentage of the offer allocated to retail, institutional, and foreign investors respectively. The value of $t$-statistics is shown in parentheses.

*,**, and ${ }^{* * *}$ represent statistically significant at $10 \%, 5 \%$, and $1 \%$, respectively.

Source: Prepared by the authors. 
Other variables that affected the magnitude and sign of the change in the issuer's share price after the expiration of the IPO lock-up were the market value, increasing the abnormal return by $2 \%$ on the expiration of the second maturity, and the allocation of investors retail, reducing return between $7 \%$ and $8.5 \%$ after the second lock-up expiration. This is in line with evidence found in the international literature. The smaller the company, the greater the uncertainty about the quality of the IPO. Therefore, the greater the fall in return after the restriction window for the sale of shares by insiders. The greater the retail investors' presence, the greater the volatility in the issue price after the launch and, consequently, the greater the price drop after the lock-up expires. The allocation of institutional investors increased the abnormal return by about $8 \%$ after the lock-up expiration on subsequent offers, while subsequent offers were listed on Novo Mercado. This last result is unexpected because it is the highest level of corporate governance at B3. Therefore, companies that meet these criteria are expected to have a higher degree of transparency, and a lower level of information asymmetry, mitigating negative abnormal returns.

\section{CONCLUSIONS}

To verify the effects of the lock-up period expired on the behavior of shares' prices and volume, this article investigated all IPOs and follow-ons occurring in the Brazilian market between 2004 and 2019.

In the total IPO sample, evidence of $-2.11 \%$ negative and significant abnormal returns was found around the expiration of the second lock-up window, which is in line with evidence found in the United States, MENA, Malaysia, and the United Kingdom. However, the significance of this effect in Brazil disappears when the test's robustness is increased, building the cumulative abnormal returns from risk-adjusted benchmarks. As several of the evidence of return drops reported in the international literature were observed with abnormal returns built from the market model, i.e., due to the difference between the return on the stock and the return on the main stock index in the country, this result may become insignificant in several countries with the use of more robust benchmarks.

The presence of private equity funds in the shareholding structure of companies before going public, controlled by variables that may impact the return, increased the magnitude of the fall after the expiration of the first lockup window by around 5\% a $6 \%$. Private equity funds have a deadline for divesting and returning the invested capital to shareholders and, therefore, tend to increase the intensity of negative abnormal returns, given the selling pressure that may occur after the lock-up of the shares held by them expires. This result is consistent with those obtained in international studies by Ofek and Richardson (2000) and Field and Hanka (2001).

It is interesting to note that, while more than half of Brazilian IPOs were from companies invested by private equity funds, less than $6 \%$ of follow-ons were from companies with financial investors. Moreover, in the follow-ons, private equity funds' presence did not increase the magnitude of the stock's decline after the lock-up expiration. This probably indicates a preference for private equity funds to sell their equity position after the restriction window expires on the initial issue itself, using fewer subsequent issues to sell their positions. As these are assets already traded on the stock exchange, there is not the same selling pressure on insiders after the lockup expires since they could have already divested their positions previously. However, it should be noted that the low number of offers with private equity in sample 9 , in Panel B of Table 1, did not allow to obtain conclusive results.

The fall in the share price after the lock-up expiration in the IPOs of companies invested by private equity also indicates a restriction on short selling in Brazil, which prevents arbitrators from fully exploiting this inefficiency line with the evidence found by Ofek and Richardson (2000). The IPOs of companies financed by private equity have a significant cumulative return up to 5 days before the lock-up expiration. It indicates that, probably, there were transactions to arbitrate this opportunity; but, due to restrictions on short sales, the volume traded was not sufficient to eliminate the price drop after the lock-up expiration, which is consistent with the evidence found by Gibbs and Hao (2018) in the stock market of the United States.

The effect of the lock-up expiration on companies not financed by private equity funds is contrary to the results of tests carried out in most countries. Instead of falling, there was an increase in the cumulative abnormal return in the 22 days following the lock-up expiration. The fact that shares of family businesses predominate in B3, with families wanting to remain in control after the IPO, may explain this fact, which may be the subject of further research.

As a proposal for future research and given the evidence that there is a negative influence on returns and an increase in the volume traded after the lock-up in the presence of 
private equity, it is suggested to check whether it would be possible to adopt a stock rental and sale strategy to capture the negative abnormal return. The increase in the number of leased shares of the issuing companies around the lock-up expiration dates could be assumed as a proxy to measure this hypothesis. If this strategy is economically viable and there are no restrictions on sales discovered in the Brazilian market, the abnormal negative performance of the assets could be arbitrated by investors and, therefore, would tend to be eliminated.

Finally, it is worth mentioning a new type of lockup applied to Brazilian offers - the lock-up applied to private (high-income) and retail investors, something unprecedented in stock offers. This new lock-up modality first appeared in Petrobras' follow-on, priced in June 2019, and was replicated in the initial offers by Vivara and Banco BMG, in addition to the subsequent offer by Banco do Brasil. The lock-up period defined in these offers for these investors ranged from 45 to 120 days.

While beneficial for the long-term investor, as it gives priority to the allocation and eventual apportionment of the shares, it is an unusual use and with another purpose of the lock-up mechanism, since private and retail investors do not have privileged access to company information, such as insiders, and whose sole purpose is to reduce the initial volatility of securities. As it is a recent topic, the effects on the actions after their expiration could be the subject of further research.

\section{REFERENCES}

Achmadsyah, V. A. (2016). Lock-up length and its implication for post-IPO performance. (Dissertação de Mestrado). Erasmus University Rotterdam, Roterdã.

Boreiko, D., \& Lombardo, S. (2013). Lock-up clauses in Italian IPOs. Applied Financial Economics, 23(3), 221-232.

Bradley, D. J., Jordan, B. D., Yi, H., \& Roten, I. C. (2014). Venture capital and IPO lock-up expiration: an empirical analysis. Journal of Financial Research, 24(4), 465-493.

Brav, A., \& Gompers, P. A. (2003). The role of lock-ups in initial public offerings. Review of Financial Studies, 16(1), 1-29.

Castro, C. S. C. M. (2013). O comportamento do preço de IPOs ao redor do vencimento do lock-up. (Dissertação de Mestrado). Insper Instituto de Ensino e Pesquisa, São Paulo.

Christensen, M. (2012). Lock-up expirations in Brazilian IPOs. (Dissertação de Mestrado). KTH Industrial Engineering and Management, Estocolmo.

Fama, F., \& French, R. (1993). Common risk factors in the returns stocks and bonds. Journal of Financial Economics, 33, 3-56.

Field, L. C., \& Hanka, G. (2001). The expiration of IPO share lockups. The Journal of Finance, 56(2), 471-500.

Gao, S., Liu, J., \& Chan, K. C. (2017). Does the removal of the IPO lock-up matter in IPO pricing? Finance Research Letter, 23, 246-252.

Gibbs, M., \& Hao, Q. (2018). Short selling around the expiration of IPO share lock-ups. Journal of Banking and Finance, 88, 30-43.

Goergen, M., Renneboog, L., \& Khurshed, A. (2006). Explaining the diversity in shareholder lock-up agreements. Journal of Financial Intermediation, 15( 2), 254-280.
Hakim, T., Lypny, G., \& Bhabra, H. S. (2012). IPO lock-up expiration in the Middle East and North Africa. Journal of Multinational Financial Management, 22(5), 252-262.

Hoque, H. (2011). The choice and role of lock-ups in IPOs: evidence from heterogeneous lock-up agreements. Journal of Financial Markets, Institutions \& Instruments, 20(5), 191-220.

Leal, R. P. C. (2004). Using accounting information in prospectuses to invest in Brazilian IPOs during high inflation years. Latin American Business Review, 5(3), 65-90.

Minardi, A. M. A. F., Moita, R. M., \& Castanho, R. P. (2015). Investigating the partial adjustment effect of Brazilian IPOs. Journal of Business Research, 68(2), 189-198.

Mohamed-Arshad, S. B., Taufil-Mohd, K. N., \& Ahmad-Zaluki, N. A. (2016). IPO lock-up expiration and share price effect in Malaysian market. International Journal of Business and Social Science, 7(4), 108-113.

Ofek, E., \& Richardson, M. (2000). The IPO lock-up period: implications for market efficiency and downward sloping demand curves. New York University, Leonard N. Stern School Finance Department, Working Paper Series 99-054.

Ritter, J. R. (2006). Some factoids about the 2006 IPO market. Retrieved from $<$ http://bear.cba.ufl.edu/ritter $>$.

Securato, C. R. T. (2011). O impacto do vencimento do período de lock-up dos IPOs no preço das ações do mercado acionário brasileiro. (Dissertação de Mestrado). Pontifícia Universidade Católica de São Paulo, São Paulo.

Silva, J. M. A., \& Famá, R. (2011). Evidência de retornos anormais nos processos de IPO na Bovespa no período de 2004 a 2007: um estudo de evento. RAUSP, 46(2), 178-190. 